\title{
Assessment of New Sustainable Housing Project in Gdynia Using Justification Tools for Health-Promoting Urban Design and Architecture
}

\author{
Monika Trojanowska ${ }^{1 *}$ (1)
}

${ }^{1}$ Bydgoszcz University of Science and Technology, Bydgoszcz, POLAND

*Corresponding Author: m41troj@gmail.com

Citation: Trojanowska, M. (2022). Assessment of New Sustainable Housing Project in Gdynia Using Justification Tools for Health-Promoting Urban Design and Architecture. European Journal of Sustainable Development Research, 6(1), em0179. https://doi.org/10.21601/ejosdr/11581

\begin{tabular}{|c|c|}
\hline ARTICLE INFO & ABSTRACT \\
\hline Received: 2 Nov. 2021 & This paper presents the assessment of Gdynia-Zachód-a new sustainable housing project in Gdynia. This \\
\hline Accepted: 18 Jan. 2022 & $\begin{array}{l}\text { assessment uses a series of justification tools: the universal standard for health-promoting places and the } \\
\text { universal standard for eco-neighborhood design. The first tool evaluates the therapeutic qualities of public open } \\
\text { green space-public park and walkability of pathways leading to open green space. The second one assesses the } \\
\text { basic sustainability standards and lifestyle quality. Gdynia-Zachód is a flagship urban development based on a } \\
\text { new urbanism charter. The charette and workshops were organized to invite public participation in this project. } \\
\text { The project is still under development, but it was assumed it is a good moment for the assessment to justify future } \\
\text { design decisions. This study also demonstrated the practical usage of the universal standards as justification } \\
\text { tools. }\end{array}$ \\
\hline
\end{tabular}

Keywords: eco-neighborhoods, health-promoting urban places, universal pattern, assessment tools

\section{INTRODUCTION}

The objectives of the paper are as follows:

1. The main objective is to present an assessment of a new flagship of sustainable housing projects in Gdynia using justification tools for health-promoting urban design and architecture.

2. The additional objective presents potential strategies on how to improve the health-promoting qualities of that housing projects through urban planning and design,

3. The case study example presents the justification tools for health-promoting urban design and architecture.

It aims to shed further light on practical ways to implement the theoretical research on health-promoting urban places into the practice of eco-neighborhoods design and improve the quality of life through urban planning and design. The outcomes of this paper may provide a refinement to existing literature and implementation models of health-promoting urban design and architecture. They can provide theoretical and methodological guidance for further empirical research.

There is a plethora of research on the impact of urban design on human well-being. Gesler (1996: 96, 2005) proposed the concept of therapeutic landscape. He defined therapeutic landscapes as follows:

\section{"physical and built environments, social conditions and human perceptions combine to produce an atmosphere which is conducive to healing."}

Based on therapeutic landscapes, the concept of healthpromoting places was coined to define the everyday places that unite the qualities of therapeutic landscapes, i.e., material aspects, social constructions, symbolic significances, and allegories of positive aspects of human health and well-being to influence people physical, mental and spiritual healing (Trojanowska and Sas-Bojarska, 2018). Considerable research evidences the importance of regular contact with nature for health promotion and longevity (CABE, 2010; Edwards and Tsouros, 2008; Marcus and Sachs, 2014; Salingaros and Masden, 2008; Takano et al., 2002; Ulrich, 2008; Webster et al., 2014). Research document that urban design can promote health and longevity (Alexander et al., 1977; Antonovsky, 1996; Bell, 2012, 2017; Corburn, 2009; Register, 2006; Wakefield and McMullan, 2006). Mouratidis (2021), after extensive literature review, listed the following categories of urban planning strategies for improving subjective well-being (SWB) in cities: integration of urban nature, easy access to socially inclusive public spaces, high-quality communal 


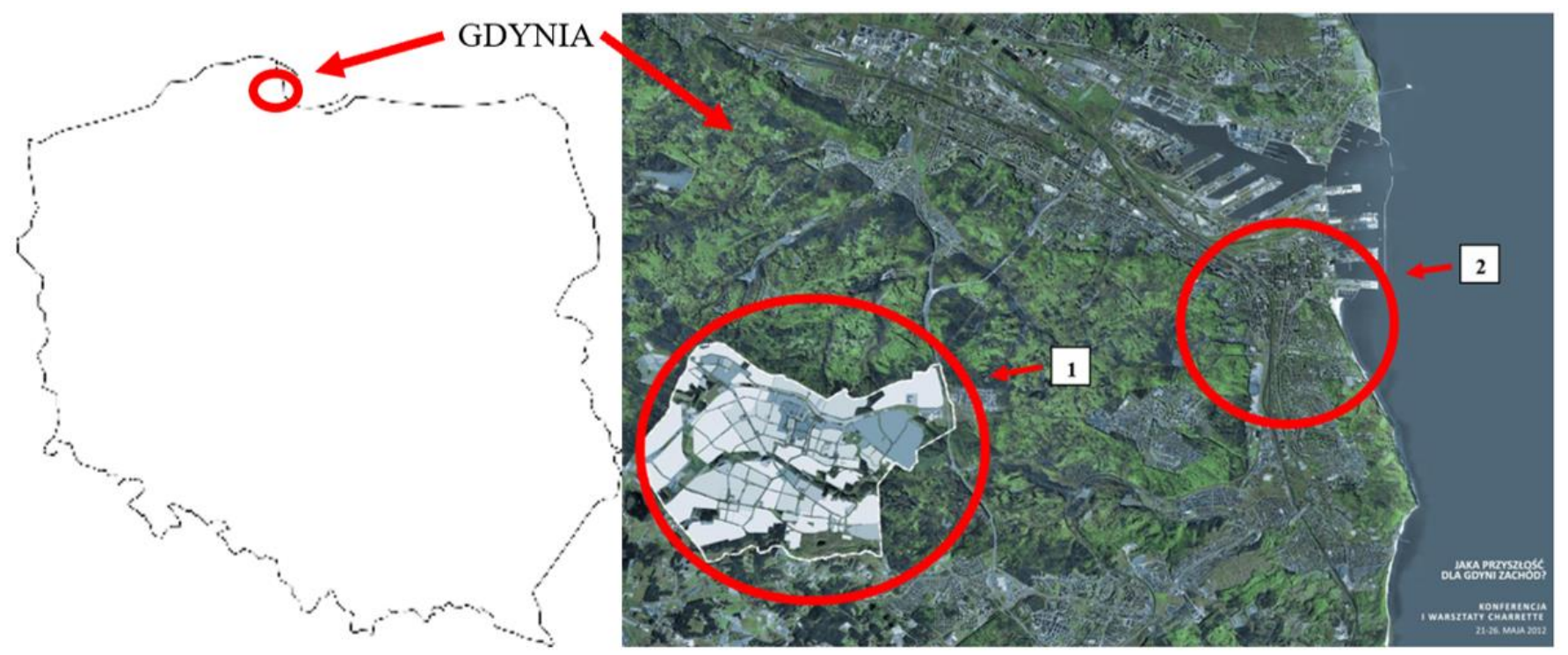

Figure 1. Location of case study. (a) Map of Poland, Source: Authors own elaboration; (b) Map of Gdynia, 1 - Gdynia Zachód, 2 Gdynia city centre (Source: Authors own elaboration using map: http://gdyniazachod.pl/index.php?parent_id=71\&menu_id=1)

spaces, easy and equitable access to a diversity of facilities and services, active travel and public transport, development of information and communications technology, maintenance of urban spaces, noise reduction, aesthetic quality, socio-spatial equity, and knowledgeable evidence-based urban planning processes.

Those research findings provide valuable insights. However, the identified gap in knowledge concerns the implementation strategies. The research question is how to put these findings into the planning practice? To what extent are the modern sustainable neighborhoods designed according to research evidence? The sustainable development and high quality of life pair in contemporary eco-neighborhoods. We can find examples of sustainable neighborhoods in many European countries: e.g., Hammarby Sjöstad in Stockholm, Vauban in Fribourg, Eva Lanxmeer in Amsterdam, and over 50 certified eco-neighborhoods in France. This study focuses on a flagship project developed in Gdynia, Poland. There are numerous challenges and opportunities for urban development in Poland (Denis et al., 2021). Some are similar to the worldwide situation, but specific local circumstances result from historical and geopolitical struggles of central European post-communistic societies.

\section{STUDY AREA: NEW NEIGHBORHOOD STRIVING FOR SUSTAINABLE DEVELOPMENT}

In Gdynia, at the tip of northern Poland, an ambitious new housing project was launched at the beginning of the XXI. century (Figure 1). The garden city ideas and charter for new urbanism provided the theoretical bases for this development. The charrette and workshops were organized in 2012, from 22 to 25 May 2012, in the new kindergarten at Staniszewskiego street. All the stakeholders: representatives of Gdynia Municipal Office, urban planners from the Gdańsk University of Technology, specialists from the Hossa S.A.-major investor and developer, and representatives of the local community, as well as local and international well-known experts.

For three days, the Charette focused on three standard solutions for:

1. Effective transportation strategies,

2. Sustainable development of the districts and creation of local workplaces, and

3. Design of friendly public space.

A vital part of Charette was a meeting with the local community, which gathered around 80 people.

Part of the ambitious project set in 2012 has already been constructed until 2019. This new neighborhood was chosen for assessment using a series of justification tools. The fulfillment of sustainable development goals was evaluated for the stage of development as it was in the summer of 2019. At the same time, the creation of health-promoting urban places was assessed using the tool prepared to evaluate therapeutic landscapes and the qualities of walkways. The new neighborhood boundaries encompass approx. $27 \mathrm{~km}^{2}$, which is $20 \%$ of the area of the entire city. $45 \%$ of the new neighborhood area is covered by forest-A Tri-City Landscape Protection Park. The development of the new neighborhood was set a priority among the town spatial policies.

The local private development company Hossa is constructing the vast majority of the new neighborhood. This housing project is still under construction, but six housing complexes are already mostly finished and inhabited: Sokółka I, Fort Forest, Sokółka II, Sokółka-Zelenisz, Patio Róży, and Wiczlino-Ogród. Their design and materials differ. They are sold to individual buyers, and the offer is diversified to target various budgets. There are apartments offered for different price ranges. Fort Forest is the most upscale and expensive, Patio Róży and Wiczlino-Ogród more affordable. Part of the social and commercial infrastructure of the new neighborhood has also been constructed (Figure 2 and Figure 3). GdyniaZachód is a flagship urban development based on a new urbanism charter. The charette and workshops were organized 

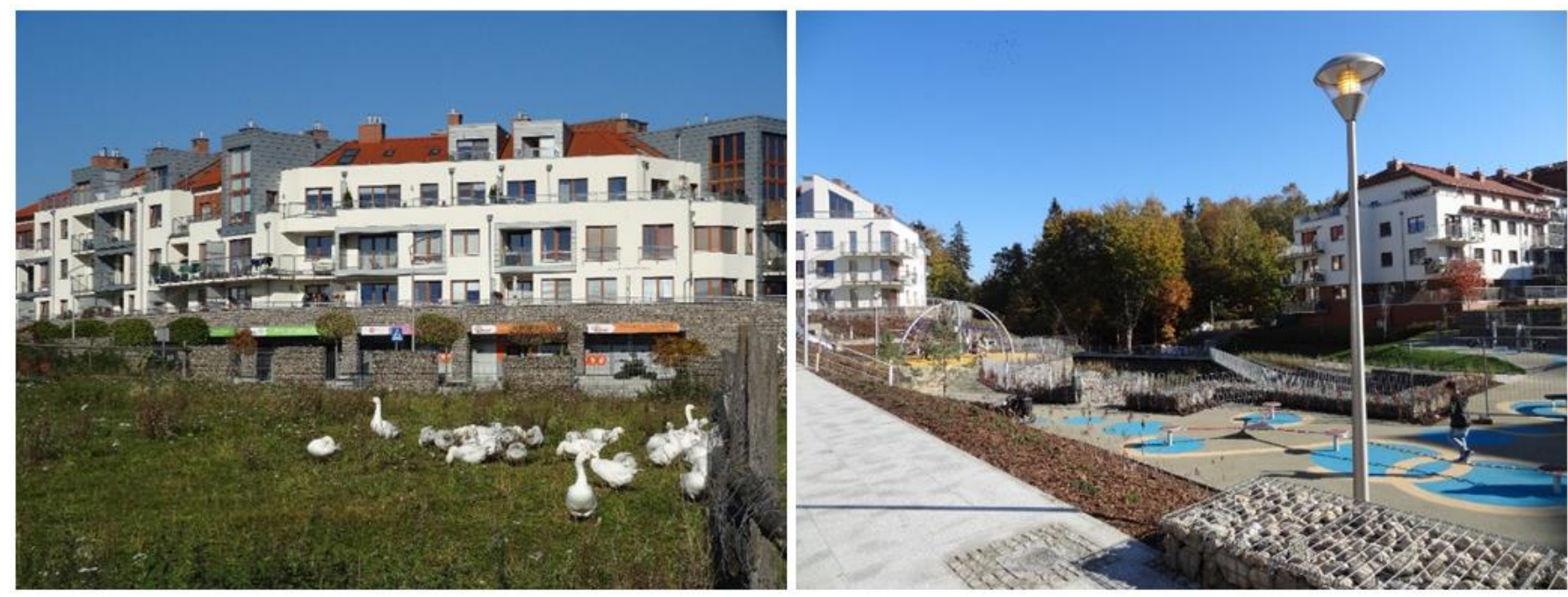

Figure 2. Goose happily sunbathing in front of Fort Forest \& the colorful playground and rainwater basin in Fort Forest-upscale residential part of Gdynia Zachód housing project. Photo source: Author
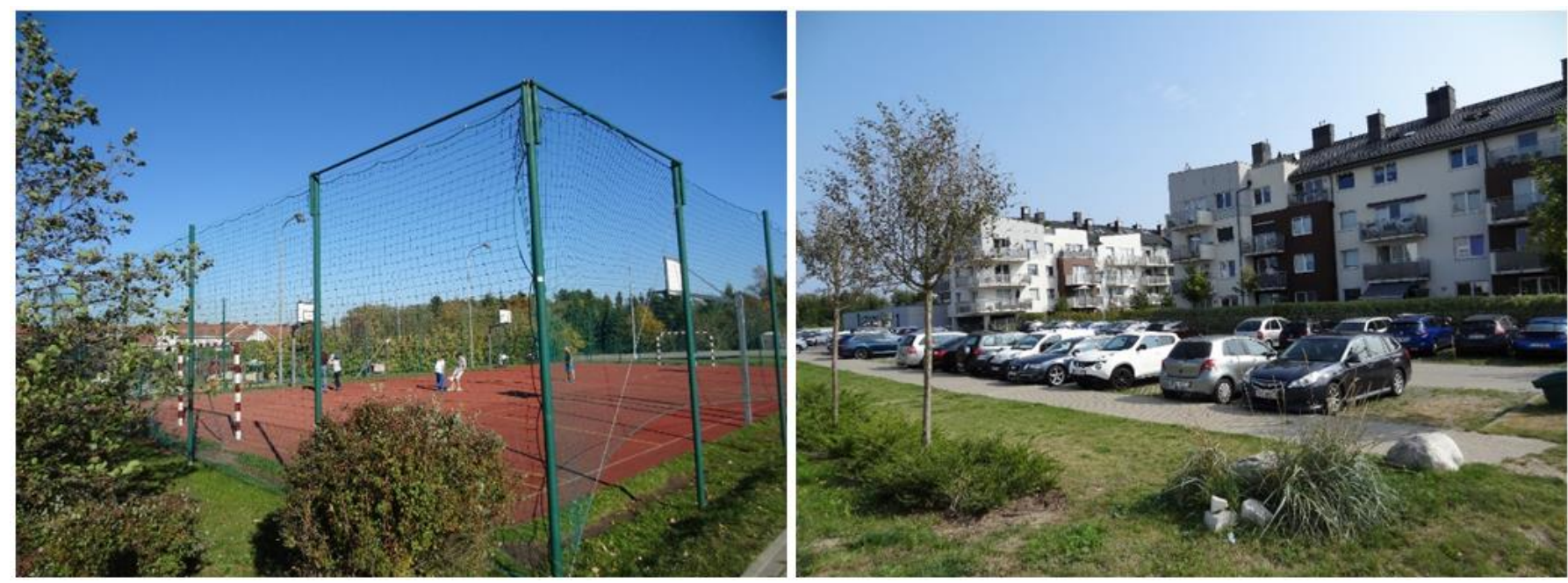

Figure 3. Sport field in the center of Gdynia Zachód housing project (left) \& Permeable parking (Patio róży-affordable complex) in Gdynia Zachód housing project (right). Photo source: Author

to invite public participation in this project. Therefore, this neighborhood was chosen for this study.

\section{METHODS}

This study assessed the Gdynia-Zachód neighborhood with two justification tools developed by the researcher: the universal standard for health-promoting places and econeighborhoods design. This research was also performed to demonstrate the practical usage of the universal standards. The universal standards for the design are ready-to-use tools for the designers, developers, and the general public. They can be used to assess the therapeutic and health-promoting qualities of public space and the sustainable development of any housing project. They can also be used as justification tools to explain the design decisions to inhabitants, decisionmakers, and local authorities. They are based on long-term research and field studies followed by theory triangulation (Trojanowska, 2021a, 2021b).

For this study, the researcher used two universal patterns simultaneously.
1. The universal standard for health-promoting places (Appendix A) can be used as an audit tool to determine the potential health-promoting qualities of urban places (Trojanowska, 2021a).

2. The universal standard for sustainable econeighborhoods (Appendix B) can be used as an audit tool to determine the potential health promotion qualities of neighborhoods and residential projects (Trojanowska, 2018).

The first tool evaluates the therapeutic qualities of public open green space-public park and walkability of pathways leading to open green space. The second one assesses the basic sustainability standards and lifestyle quality. The project is still under development, but it was assumed a good moment for the assessment to justify future design decisions.

One researcher visited the housing project several times over four years-2018-2021 and assessed the entire new neighborhood, treated as a large-scale public park of the new generation with buildings and roads inside. The presence of fences and gated communities were perceived as the major obstacle at this assessment phase. 


\section{RESULTS OF ASSESSMENT WITH THE UNIVERSAL STANDARD FOR HEALTH- PROMOTING PLACES AND SUSTAINABLE ECO-NEIGHBORHOOD DESIGN}

Both a thick binary and a detailed assessment were performed when applicable.

The thick binary assessment has two categories $(0,1)$ :

No, not observed-0,

Yes, satisfactory-1,

Data NA stands for data not available.

There are some criteria where the points count is not applicable.

The results of both rough and detailed assessments were put in Table 1 and Table 2.

The assessment of therapeutic qualities determined the following strong points of the park: natural scenic beauty, associated with opportunities for physical and mental regeneration in the forest and landscaped gardens, and protecting biodiversity and wildlife. These points are crucial and responsible for this neighborhood's popularity among users. The polluted surface waters, especially the Kacza river, need urgent remediation.

On the other hand, the assessment helped to determine opportunities for improvement: lack of comfortable seating along the walkways for the elderly and disabled (with backrests and armrests), limited places with recreational equipment for various age groups of children and adults, neither community gardens nor edible plants, and no garden pavilions to provide shelter. Other points for possible improvement included: drinking fountains, better pronounced focal points and pockets of activities, and equipment to facilitate meetings and gatherings, e.g., an open-air theatre.

The organization of space and functions was assessed as highly satisfactory. However, there is a place for improvement of urban composition. The structure could be more orderly organized, and focal points could be more pronounced. Another suggestion is to plant more edible plants.

There are numerous opportunities for improvement in the placemaking category, e.g., organization of temporary events, installation of exhibitions, and community gardens.

The new neighborhood scored almost all the points when it comes to sustainable development.

The results of the detailed evaluation of access to the park demonstrated some deficiencies. The researcher evaluated nine streets and observed some sidewalks and drainage weaknesses on Dulina, Staniszewskiego, Bryły, Sokoła, and Wiczlińska street. What was noted was the lack of seating along all of the roads leading to the park, which could hinder the frequency of park visits, especially among the elderly. Street greenery could also be improved, and rain gardens installed.

The assessment for sustainable eco-neighborhood design was performed for the entire new neighborhood. Both a thick binary and a detailed evaluation were conducted when applicable. The thick binary assessment has three categories $(0,1 / 2,1)$ :

No, not observed-0,

Yes, satisfactory-1,

Partially-1/2,

Data NA stands for data not available.

There are some criteria where the points count is not applicable. The results of both rough and detailed assessments are presented in Table 3.

\section{DISCUSSION}

The project is still under construction, but some points to consider: the space next to the new buildings was wellmaintained and inviting. There are some benches as well as playgrounds for children. The space in between the development-resembles natural meadows. Open green space can be perceived as a park of the new generation. However, there are public spaces with no visible human maintenance. The significant drawbacks are lack of seating, lighting, and sometimes even pedestrian paths. They should be installed to increase the user's comfort. Another question is the scale of the neighborhood. There is only one sports field for such a large-scale project. There should be multiples installed in various open green areas-close to the apartment buildings (Gerlach-Springs et al., 1998; Marcus and Barnes, 1995, 1999; Trojanowska, 2017, 2018, 2019, 2020; Trojanowska and SasBojarska, 2018; Wilkonson \& Marmot, 2003). One of the significant drawbacks is the fencing which separates public spaces. Gated communities hinder the possibilities of strolls and communication of people from various parts of this residential project (CABE, 2010).

The primary question about health-promoting places is the quality of living for the first pioneering inhabitants. The public park should be developed first. It should be a priority over the development of apartment blocks. The detailed evaluation of access to the park demonstrated some deficiencies. Nine streets were evaluated, and some sidewalks and drainage deficiencies were observed: Dulina, Staniszewskiego, Bryły, Sokoła, and Wiczlińska street. What was noted was the lack of seating along the roads leading to the park, which could hinder the frequency of park visits, especially among the elderly (CABE, 2010; Corburn, 2009). Street greenery and rain gardens installation could also be improved.

The project included the development of agricultural land in a controlled manner. There is no place for growth in Gdynia. The city is located between the hills covered by scenic parks and shorelines. Therefore, behind the forested hills, the terrain to the west was chosen for development. The significant advantages are the scenic beauty of this place and the environmental qualities of the natural landscape (Bell, 2012).

The drawbacks are typical for new neighborhoods: homogeneity of housing blocks, lack of commercial offers to cater to everyday needs, and no local workplaces (CABE, 2010). The dwellers have to commute to their workplaces, adding traffic and wasting much time traveling. Gradually, the functional diversity is growing, as new nurseries, 
Table 1. Assessment of health-promoting urban landscapes-Gdynia Zachód neighborhood

\begin{tabular}{|c|c|c|c|}
\hline & $\begin{array}{c}\text { Rough } \\
\text { assessment }\end{array}$ & Detailed assessment & Suggestions for improvement \\
\hline \multicolumn{4}{|l|}{ UNIVERSAL DESIGN } \\
\hline Place & NA & & \\
\hline Area, approximately & $25 \mathrm{~km} 2$ & & \\
\hline Location & $\begin{array}{l}\text { Surrounded } \\
\text { by a forest }\end{array}$ & $\begin{array}{l}\text { Western part of city limits, dense natural forest } \\
\text { between the city center and new neighborhood }\end{array}$ & \\
\hline Surrounding urban pattern & $\begin{array}{l}\text { Loose urban } \\
\text { tissue }\end{array}$ & Single and multifamily buildings, rural development & \\
\hline Environmental characteristics & NA & & \\
\hline Soil quality & Good & Former agricultural soils, no traces of pollution & \\
\hline Water quality & $\begin{array}{l}\text { Bad quality of } \\
\text { surface } \\
\text { waters }^{\mathrm{a}} \\
\end{array}$ & $\begin{array}{l}\text { Non-potable water in the ponds, polluted waters of } \\
\text { the Kacza river }\end{array}$ & $\begin{array}{l}\text { The polluted waters needs urgent } \\
\text { remediation }\end{array}$ \\
\hline Air quality & Good $^{\mathrm{b}}$ & Good air circulation & \\
\hline Biodiversity & $\begin{array}{l}\text { Rich in } \\
\text { species }\end{array}$ & Forest habitat for many species of insects and birds & \\
\hline Forms of nature protection & No & No & \\
\hline Universal accessibility & Accessible & $\begin{array}{c}\text { Pathways are wide and even, majority of } \\
\text { neighborhood is accessible }\end{array}$ & Accessibility could be improved \\
\hline Access to park & NA & & \\
\hline Distance to potential users & $\begin{array}{l}\text { Less than } \\
500 \mathrm{~m} \text {, over } \\
500 \mathrm{~m}\end{array}$ & $\begin{array}{l}\text { People who live in surrounding buildings, people who } \\
\text { use public transport, inhabitants of Gdynia who are } \\
\text { strolling along the paths in the forest }\end{array}$ & \\
\hline Public transport stops & Yes & Numerous bus stops & \\
\hline Walkways to park & Multiple & $\begin{array}{c}\text { Additional evaluation of streets leading to park } \\
\text { presented below }\end{array}$ & \\
\hline \multicolumn{4}{|l|}{ PARK'S FUNCTIONAL PROGRAM } \\
\hline $\begin{array}{l}\text { Psychological and physical } \\
\text { regeneration }\end{array}$ & 1 & Numerous possibilities & \\
\hline Natural landscapes & 1 & Natural forests and meadows & \\
\hline Green open space & 1 & multiples & \\
\hline $\begin{array}{l}\text { Place to rest in the sun and in } \\
\text { the shade }\end{array}$ & 1 & $\begin{array}{l}\text { Multiples in close proximity to houses, lack of seating } \\
\text { along walkways further away from the houses }\end{array}$ & $\begin{array}{c}\text { The benches have no backrests neither } \\
\text { armrests }\end{array}$ \\
\hline $\begin{array}{l}\text { Place to rest in silence and } \\
\text { solitude }\end{array}$ & 1 & $\begin{array}{l}\text { Multiples in close proximity to houses, lack of seating } \\
\text { along walkways further away from the houses }\end{array}$ & \\
\hline $\begin{array}{l}\text { Possibility to observe other } \\
\text { people }\end{array}$ & 1 & $\begin{array}{l}\text { There are many places to observe activities of other } \\
\text { people }\end{array}$ & \\
\hline Possibility to observe animals & 1 & There are many places to observe wildlife & \\
\hline Social contacts enhancement & 1 & & \\
\hline $\begin{array}{l}\text { Organization of events inside } \\
\text { the park }\end{array}$ & 1 & Open green areas can serve to organize events & \\
\hline Gathering place for groups & 1 & There are spatial possibilities to organize meetings & $\begin{array}{l}\text { It would be useful to build garden pavilions } \\
\text { with running potable water and electricity }\end{array}$ \\
\hline Physical activity promotion & 1 & & \\
\hline $\begin{array}{l}\text { Sports and recreational } \\
\text { infrastructure }\end{array}$ & 1 & $\begin{array}{c}\text { Limited places with recreational infrastructure for } \\
\text { various age groups }\end{array}$ & $\begin{array}{c}\text { Provide more places with recreational } \\
\text { infrastructure for various age groups }\end{array}$ \\
\hline Community gardens & 0 & There are no community gardens & $\begin{array}{l}\text { Install community gardens. Generous space } \\
\text { of new neighborhood offers possibilities for } \\
\text { organizing the community gardens }\end{array}$ \\
\hline Catering for basic needs & 1 & & \\
\hline Safety and security & 1 & $\begin{array}{l}\text { Assessed as safe place. The neighborhood is well } \\
\text { maintained, clean and offers good visibility }\end{array}$ & \\
\hline Places to sit and rest & 1 & There are numerous benches & $\begin{array}{l}\text { It would be useful to install movable chairs, } \\
\text { and various benches with back and armrests } \\
\text { along the walkways }\end{array}$ \\
\hline Shelter & 0 & & It would be useful to install garden pavilions \\
\hline Restrooms & 0 & & $\begin{array}{l}\text { It would be useful to construct public toilets } \\
\text { next to places with recreational } \\
\text { infrastructure, playgrounds, sport fields, etc. }\end{array}$ \\
\hline Drinking water & 0 & & $\begin{array}{l}\text { It would be useful to install drinking } \\
\text { fountains along the fountains and next to } \\
\text { places with recreational infrastructure, } \\
\text { playgrounds, sport fields, etc. }\end{array}$ \\
\hline
\end{tabular}

kindergartens, and public facilities are being constructed in the neighborhood. 
Table 1 (Continued). Assessment of health-promoting urban landscapes-Gdynia Zachód neighborhood

\begin{tabular}{|c|c|c|c|}
\hline & $\begin{array}{c}\text { Rough } \\
\text { assessment }\end{array}$ & Detailed assessment & Suggestions for improvement \\
\hline Food & 0 & & $\begin{array}{l}\text { It would be useful to allow construction of a food } \\
\text { stands next to places with recreational } \\
\text { infrastructure, playgrounds, sport fields, etc. }\end{array}$ \\
\hline \multicolumn{4}{|c|}{ ORGANISATION OF SPACE AND FUNCTIONS } \\
\hline $\begin{array}{l}\text { The park spatial composition } \\
\text { follows the surrounding urban } \\
\text { pattern }\end{array}$ & 1 & $\begin{array}{l}\text { Park fills the space between the buildings, fills } \\
\text { the urban tissue }\end{array}$ & \\
\hline $\begin{array}{l}\text { Architectural variety of urban } \\
\text { environment }\end{array}$ & 1 & $\begin{array}{l}\text { To some extend we can observe the architectural } \\
\text { variety, however some housing complexes are } \\
\text { constructed with repeated buildings }\end{array}$ & \\
\hline Focal points and landmarks & 1 & $\begin{array}{l}\text { It would be useful to install focal points that } \\
\text { would be more pronounced }\end{array}$ & \\
\hline $\begin{array}{l}\text { Structure of interiors and } \\
\text { connections }\end{array}$ & 1 & & $\begin{array}{l}\text { The structure could be more orderly organized } \\
\text { and focal points could be more pronounced }\end{array}$ \\
\hline Long vistas (Extent) & 1 & $\begin{array}{l}\text { Yes, the neighborhood offers numerous long } \\
\text { vistas }\end{array}$ & \\
\hline Pathways with views & 1 & yes & \\
\hline $\begin{array}{l}\text { Invisible fragments of the } \\
\text { scene (Vista engaging the } \\
\text { imagination) }\end{array}$ & 1 & Yes, numerous designed vistas & \\
\hline Mystery, fascination & 1 & $\begin{array}{l}\text { Forest trails offers the feeling of mystery and } \\
\text { fascination }\end{array}$ & \\
\hline Framed views & 1 & Numerous framed views & \\
\hline Human scale & 1 & The neighborhood is designed in human scale & \\
\hline Optimal level of complexity & 1 & Yes & \\
\hline Natural surfaces & 1 & Yes & \\
\hline Engaging features & 1 & Multiple elements attract human attention & \\
\hline Risk/Peril & 1 & $\begin{array}{c}\text { Multiple elements offer the subjective feeling of } \\
\text { overcoming controlled risk }\end{array}$ & \\
\hline Movement & 1 & Water, greenery & \\
\hline Presence of water & 1 & $\begin{array}{c}\text { Presence of water increases the recreational } \\
\text { values of space }\end{array}$ & \\
\hline Sensory stimuli design & 1 & & \\
\hline Sensory stimuli: Sight & 1 & Numerous elements & \\
\hline Sensory stimuli: Hearing & 1 & Plants & \\
\hline Sensory stimuli: Smell & 1 & Plants & \\
\hline Sensory stimuli: Touch & 1 & Plants & \\
\hline Sensory stimuli: Taste & 0 & & It would be useful to plant edible plants \\
\hline \multicolumn{4}{|l|}{ PLACEMAKING } \\
\hline Works of art & 0 & & $\begin{array}{c}\text { It could be interesting to organize temporary } \\
\text { exhibitions of sculpture }\end{array}$ \\
\hline Monuments in the park & 0 & No & $\begin{array}{l}\text { It could be interesting to install a table with this } \\
\text { place history }\end{array}$ \\
\hline Historic places & 1 & Local shrines & \\
\hline $\begin{array}{l}\text { Culture and connection to the } \\
\text { past }\end{array}$ & 1 & Remaining rural development & \\
\hline Thematic gardens & 0 & & $\begin{array}{l}\text { It could be interesting to install thematic } \\
\text { gardens, e.g. community gardens }\end{array}$ \\
\hline Personalization & 1 & During organized events & \\
\hline Animation of place & 1 & During organized events & \\
\hline \multicolumn{4}{|l|}{ Community engagement } \\
\hline $\begin{array}{l}\text { Personalizing the architectural } \\
\text { process }\end{array}$ & 1 & $\begin{array}{l}\text { Yes, the names of people involved in the project } \\
\text { are known }\end{array}$ & \\
\hline $\begin{array}{l}\text { Participation of all } \\
\text { stakeholders, including } \\
\text { inhabitants and users }\end{array}$ & 1 & $\begin{array}{c}\text { The charrettes, meetings, and other forms of } \\
\text { organized participation }\end{array}$ & \\
\hline $\begin{array}{l}\text { Determining the rules of } \\
\text { conduct and self-management }\end{array}$ & 1 & Yes, the rules of conduct are determined & \\
\hline Space for social contact & 1 & & \\
\hline Third places & 1 & $\begin{array}{c}\text { Numerous places: cafes, restaurants, clubs, shops, } \\
\text { etc. }\end{array}$ & \\
\hline Fourth places & 1 & $\begin{array}{l}\text { Interesting in-between spaces, public open } \\
\text { spaces, cafes, shops, etc. }\end{array}$ & \\
\hline
\end{tabular}


Table 1 (Continued). Assessment of health-promoting urban landscapes-Gdynia Zachód neighborhood

\begin{tabular}{|c|c|c|c|}
\hline & $\begin{array}{c}\text { Rough } \\
\text { assessment }\end{array}$ & Detailed assessment & Suggestions for improvement \\
\hline \multicolumn{4}{|c|}{ PURSUIT OF SUSTAINABLE DEVELOPMENT } \\
\hline Green infrastructure & 1 & $\begin{array}{l}\text { This neighborhood is an important element of } \\
\text { green and blue infrastructure }\end{array}$ & \\
\hline $\begin{array}{l}\text { Parks of second (New) } \\
\text { generation }\end{array}$ & 1 & Can be regarded as such & \\
\hline Biodiversity protection & 1 & Numerous efforts & \\
\hline $\begin{array}{l}\text { Part of park not-available to } \\
\text { visitors }\end{array}$ & 1 & Parts of forest & \\
\hline Native plants & 1 & yes & \\
\hline Native animals & 1 & yes & \\
\hline Natural maintenance methods & 1 & yes & \\
\hline Sustainable water management & 1 & yes & \\
\hline Rainwater infiltration & 1 & Porous, permeable surfaces & \\
\hline $\begin{array}{l}\text { Irrigation with non-potable } \\
\text { water }\end{array}$ & $\begin{array}{c}\text { No } \\
\text { information }\end{array}$ & & \\
\hline Park in a flood risk zone & 1 & no & \\
\hline Urban metabolism & 1 & Waste segregation & \\
\hline
\end{tabular}

Table 2. Assessment of health-promoting urban landscapes-Gdynia Zachód neighbourhood (ACCESS TO PARK)

\begin{tabular}{|c|c|c|c|c|c|c|c|c|c|}
\hline Streets & Chwarznieńska & $\begin{array}{c}\text { A. } \\
\text { Dulina }\end{array}$ & $\begin{array}{c}\text { L. } \\
\text { Staniszewskiego } \\
\end{array}$ & $\begin{array}{c}J \\
\text { Bryła }\end{array}$ & $\begin{array}{c}\text { F. } \\
\text { Sokoła } \\
\end{array}$ & $\begin{array}{c}\text { M. } \\
\text { Zaruskiego } \\
\end{array}$ & Wiczlińska & $\begin{array}{c}\text { S. } \\
\text { Filipkowskiego }\end{array}$ & $\begin{array}{c}\text { A. } \\
\text { Krauzego }\end{array}$ \\
\hline \multicolumn{10}{|c|}{ Sidewalk infrastructure } \\
\hline $\begin{array}{l}\text { Width of } \\
\text { sidewalks }\end{array}$ & $\begin{array}{l}\text { Only fragments of } \\
\text { street have } \\
\text { sidewalks }\end{array}$ & Narrow & Narrow & $\begin{array}{c}\text { Only } \\
\text { fragments of } \\
\text { street have } \\
\text { sidewalks } \\
\end{array}$ & Narrow & $\begin{array}{c}\text { Only } \\
\text { fragments of } \\
\text { street have } \\
\text { sidewalks } \\
\end{array}$ & $\begin{array}{c}\text { Only } \\
\text { fragments of } \\
\text { street have } \\
\text { sidewalks } \\
\end{array}$ & $\begin{array}{l}\text { Only fragments of } \\
\text { street have } \\
\text { sidewalks }\end{array}$ & No sidewalk \\
\hline $\begin{array}{l}\text { Evenness of } \\
\text { surface }\end{array}$ & Uneven & $\begin{array}{c}\text { Only part of } \\
\text { the street has } \\
\text { pavement }\end{array}$ & Partially uneven & Uneven & $\begin{array}{l}\text { Partially } \\
\text { uneven }\end{array}$ & Uneven & Yes & Yes & $\begin{array}{c}\text { Uneven, } \\
\text { only part of } \\
\text { the street } \\
\text { has } \\
\text { pavement }\end{array}$ \\
\hline $\begin{array}{l}\text { Lack of } \\
\text { obstructions }\end{array}$ & $\begin{array}{c}\text { Lack of } \\
\text { obstructions }\end{array}$ & $\begin{array}{c}\text { Lack of } \\
\text { obstructions }\end{array}$ & Lack of obstructions & $\begin{array}{l}\text { Cars parked } \\
\text { on sidewalks }\end{array}$ & $\begin{array}{l}\text { Cars parked } \\
\text { on sidewalks }\end{array}$ & $\begin{array}{c}\text { Cars parked on } \\
\text { sidewalks } \\
\end{array}$ & $\begin{array}{c}\text { Lack of } \\
\text { obstructions }\end{array}$ & $\begin{array}{c}\text { Lack of } \\
\text { obstructions }\end{array}$ & $\begin{array}{c}\text { Lack of } \\
\text { obstructions }\end{array}$ \\
\hline Slope & Not important & $\begin{array}{c}\text { Not } \\
\text { important }\end{array}$ & Not important & $\begin{array}{c}\text { Not } \\
\text { important }\end{array}$ & $\begin{array}{c}\text { Not } \\
\text { important }\end{array}$ & Not important & $\begin{array}{c}\text { Yes, stairs, no } \\
\text { ramps for the } \\
\text { disabled }\end{array}$ & Not important & important \\
\hline $\begin{array}{l}\text { Sufficient } \\
\text { drainage }\end{array}$ & Sufficient & No & Lack of drainage & $\begin{array}{l}\text { Lack of } \\
\text { drainage }\end{array}$ & sufficient & $\begin{array}{l}\text { Lack of } \\
\text { drainage }\end{array}$ & $\begin{array}{c}\text { Partially lack } \\
\text { of drainage }\end{array}$ & Sufficient drainage & $\begin{array}{l}\text { Lack of } \\
\text { drainage }\end{array}$ \\
\hline \multicolumn{10}{|c|}{ General conditions } \\
\hline Maintenance & Good & $\begin{array}{c}\text { Requires } \\
\text { construction }\end{array}$ & Partially good & $\begin{array}{c}\text { Requires } \\
\text { construction }\end{array}$ & $\begin{array}{l}\text { Requires } \\
\text { renovation }\end{array}$ & $\begin{array}{c}\text { Requires } \\
\text { construction }\end{array}$ & Good & Good & No \\
\hline $\begin{array}{l}\text { Overall } \\
\text { aesthetics }\end{array}$ & Good & $\begin{array}{c}\text { Requires } \\
\text { construction }\end{array}$ & Good & $\begin{array}{c}\text { Requires } \\
\text { construction }\end{array}$ & $\begin{array}{c}\text { Requires } \\
\text { renovation }\end{array}$ & $\begin{array}{c}\text { Requires } \\
\text { construction }\end{array}$ & Good & Good & Scenic trail \\
\hline Street art & No & No & No & No & No & No & No & No & No \\
\hline $\begin{array}{l}\text { Sufficient } \\
\text { seating }\end{array}$ & No & No & No & No & No & No & No & No & No \\
\hline $\begin{array}{l}\begin{array}{l}\text { Perceived } \\
\text { safety }\end{array} \\
\end{array}$ & Good & No & No & No & No & No & No & good & good \\
\hline $\begin{array}{l}\text { Buffering } \\
\text { from traffic }\end{array}$ & $\begin{array}{l}\text { One side has a } \\
\text { buffer with } \\
\text { greenery }\end{array}$ & No & No & No & No & No & $\begin{array}{c}\text { Partially } \\
\text { buffering } \\
\text { with greenery }\end{array}$ & $\begin{array}{l}\text { Buffering with } \\
\text { greenery }\end{array}$ & No traffic \\
\hline $\begin{array}{l}\text { Street } \\
\text { activities }\end{array}$ & No & No & No & No & No & No & No & No & No \\
\hline Vacant lots & Yes & Yes & Yes & Yes & Yes & Yes & Yes & Yes & Yes \\
\hline \multicolumn{10}{|l|}{ Traffic } \\
\hline Speed & Important & Slow & Important & Slow & Slow & Slow & Important & Slow & Slow \\
\hline Volume & $\begin{array}{c}\text { Important, main } \\
\text { road }\end{array}$ & Little & Little & Little & Little & Little & Important & Little & No traffic \\
\hline $\begin{array}{l}\text { Number and } \\
\text { safety of } \\
\text { crossings }\end{array}$ & Multiples, safe & No & Multiples, safe & No & No & No & No & No & No \\
\hline Stop signs & Yes & No & No & No & No & No & No & Yes & No \\
\hline Parking & Prohibited & Yes & Yes & Yes & Yes & Yes & No & No & No \\
\hline
\end{tabular}


Table 2 (Continued). Assessment of health-promoting urban landscapes-Gdynia Zachód neighbourhood (ACCESS TO PARK)

\begin{tabular}{|c|c|c|c|c|c|c|c|c|c|}
\hline Streets & Chwarznieńska & $\begin{array}{c}\text { A. } \\
\text { Dulina }\end{array}$ & $\begin{array}{c}\text { L. } \\
\text { Staniszewskiego }\end{array}$ & $\begin{array}{c}\text { J. } \\
\text { Bryła }\end{array}$ & $\begin{array}{c}\text { F. } \\
\text { Sokoła }\end{array}$ & $\begin{array}{c}\text { M. } \\
\text { Zaruskiego }\end{array}$ & Wiczlińska & $\begin{array}{c}\text { S. } \\
\text { Filipkowskiego }\end{array}$ & $\begin{array}{c}\text { A. } \\
\text { Krauzego }\end{array}$ \\
\hline \multicolumn{10}{|c|}{ User experience } \\
\hline Air quality & Average & Average & Average & Average & Average & Average & Average & Average & good \\
\hline Noise level & Important & Important & Average & Average & Average & Average & Average & Average & little \\
\hline $\begin{array}{l}\text { Sufficient } \\
\text { lighting }\end{array}$ & Yes & No & Average & $\begin{array}{c}\text { Requires } \\
\text { construction }\end{array}$ & Yes & No & Yes & Yes & No \\
\hline $\begin{array}{l}\text { Sunshine and } \\
\text { shade }\end{array}$ & Yes & No & No & No & Yes & No & $\begin{array}{l}\text { Trees provide } \\
\text { shade }\end{array}$ & No trees & $\begin{array}{l}\text { Trees } \\
\text { provide } \\
\text { shade }\end{array}$ \\
\hline $\begin{array}{l}\text { Transparency } \\
\text { of ground } \\
\text { floors of } \\
\text { building }\end{array}$ & $\begin{array}{l}\text { Residential } \\
\text { buildings }\end{array}$ & $\begin{array}{l}\text { Residential } \\
\text { buildings }\end{array}$ & $\begin{array}{l}\text { Residential floors, } \\
\text { Property walls }\end{array}$ & $\begin{array}{l}\text { Residential } \\
\text { floors }\end{array}$ & $\begin{array}{l}\text { Residential } \\
\text { floors }\end{array}$ & $\begin{array}{l}\text { Residential } \\
\text { floors, } \\
\text { individual } \\
\text { parking }\end{array}$ & $\begin{array}{c}\text { Residential } \\
\text { floors, walls, } \\
\text { individual } \\
\text { parking }\end{array}$ & $\begin{array}{l}\text { Residential floors, } \\
\text { walls, individual } \\
\text { parking }\end{array}$ & $\begin{array}{l}\text { No } \\
\text { buildings }\end{array}$ \\
\hline
\end{tabular}

Table 3. Assessment of sustainable development of eco-neighborhood-Gdynia Zachód

\begin{tabular}{|c|c|c|c|c|}
\hline Obligatory requisite & $\begin{array}{c}\text { Optional } \\
\text { conditions }\end{array}$ & Rough assessment & Detailed assessment & Suggestions for improvement \\
\hline \multicolumn{5}{|c|}{ PLANNING OF DEVELOPMENT } \\
\hline Integrated design & & 0 & No & \\
\hline \multirow[t]{3}{*}{$\begin{array}{l}\text { Consolidation of social } \\
\text { capital }\end{array}$} & & 0 & No & \\
\hline & Participation & 1 & Yes & \\
\hline & Space for social contacts & 1 & $\begin{array}{l}\text { Yes, numerous places for } \\
\text { social contacts of various } \\
\text { age groups, e.g. } \\
\text { kindergartens, schools, } \\
\text { shops, cafes } \\
\end{array}$ & \\
\hline Accessible public transport & & 1 & $\begin{array}{c}\text { Yes, regular courses of } \\
\text { public buses }\end{array}$ & \\
\hline \multirow[t]{2}{*}{$\begin{array}{l}\text { Restraining the suburban } \\
\text { sprawl }\end{array}$} & & 1 & $\begin{array}{l}\text { Controlled urban sprawl - } \\
\text { the neighborhood was built } \\
\text { on agricultural land } \\
\text { - Gdynia Zachód }\end{array}$ & \\
\hline & $\begin{array}{l}\text { Revitalization of } \\
\text { brownfields }\end{array}$ & 0 & No & \\
\hline $\begin{array}{l}\text { Positive economic impact for } \\
\text { the city and region }\end{array}$ & & 0 & No & \\
\hline \multicolumn{5}{|c|}{ SUSTAINABLE DEVELOPMENT AND INHABITANTS HEALTH PROMOTION } \\
\hline Open public green space & & 1 & Yes & \\
\hline
\end{tabular}

Open public green space

Health-promoting urban
places
Separate tool for assessment
The universal pattern of
design for health-promoting
urban places

Public park in the center to

be developed first

\begin{tabular}{lccc}
\hline $\begin{array}{l}\text { Public park in the center to } \\
\text { be developed first }\end{array}$ & 1 & $\begin{array}{c}\text { Yes, recreational area with } \\
\text { sport fields }\end{array}$ \\
\hline & $\begin{array}{c}\text { Therapeutic park } \\
\text { Separate tool for assessment } \\
\text { The universal pattern of } \\
\text { design for health-promoting } \\
\text { urban places }\end{array}$ & Separated assessment-above \\
\hline $\begin{array}{c}\text { New (second) generation of } \\
\text { parks }\end{array}$ & 1 & Yes & no \\
\hline Community gardens & 0 & $\begin{array}{c}\text { It would be recommended to } \\
\text { facilitate creation of } \\
\text { community gardens }\end{array}$ \\
\hline Green infrastructure grid & Green streets & 1 & $\begin{array}{c}\text { Yes, inside the } \\
\text { neighborhood }\end{array}$ \\
\hline Green walls & 1 & $\begin{array}{c}\text { Yes, inside the } \\
\text { neighborhood }\end{array}$ \\
\hline Green roofs & 1 & $\begin{array}{c}\text { Covering underground } \\
\text { parking }\end{array}$ \\
\hline
\end{tabular}


Table 3 (Continued). Assessment of sustainable development of eco-neighborhood-Gdynia Zachód

\begin{tabular}{|c|c|c|c|c|}
\hline Obligatory requisite & $\begin{array}{c}\text { Optional } \\
\text { conditions }\end{array}$ & Rough assessment & Detailed assessment & Suggestions for improvement \\
\hline & Biodiversity protection & 1 & Yes & \\
\hline & $\begin{array}{l}\text { Enclosure for pets//off- } \\
\text { leash dog park }\end{array}$ & 0 & No & $\begin{array}{l}\text { It would be recommended to } \\
\text { provide enclosure for pets//off- } \\
\text { leash dog park }\end{array}$ \\
\hline \multicolumn{5}{|l|}{ Water protection } \\
\hline & $\begin{array}{l}\text { Sustainable drainage } \\
\text { systems }\end{array}$ & 1 & Yes & \\
\hline & $\begin{array}{c}\text { Stabilized permeable } \\
\text { surfaces }\end{array}$ & 1 & Yes & \\
\hline & Open drainage canals & $1 / 2$ & Partially & \\
\hline & Swales for drainage & 1 & Yes & \\
\hline & $\begin{array}{l}\text { Swales for infiltration and } \\
\text { retention }\end{array}$ & 1 & Yes & \\
\hline & Raingardens & 1 & Yes & \\
\hline & Rainwater basins & 1 & Yes & \\
\hline & Dry basins & 1 & Yes & \\
\hline & Artificial wetlands & 1 & Yes & \\
\hline \multicolumn{5}{|l|}{ Soil protection } \\
\hline & $\begin{array}{c}\text { Installations for } \\
\text { phytoremediation }\end{array}$ & Data NA & & \\
\hline & $\begin{array}{l}\text { Minimizing the building } \\
\text { perimeter }\end{array}$ & 1 & Yes & \\
\hline & $\begin{array}{c}\text { Urban metabolism, "zero" } \\
\text { waste }\end{array}$ & 1 & $\begin{array}{c}\text { Waste } \\
\text { segregation }\end{array}$ & \\
\hline & Pneumatic waste collection & 0 & No & \\
\hline & $\begin{array}{c}\text { Natural maintenance of } \\
\text { green areas }\end{array}$ & 1 & Yes & \\
\hline & Composting & 0 & No & \\
\hline \multicolumn{5}{|l|}{ Air protection } \\
\hline & Ecological heating & 1 & Yes & \\
\hline & HVAC & Data NA & & \\
\hline & Natural daylight & 1 & Yes & \\
\hline & $\begin{array}{l}\text { Energy efficiency of every } \\
\text { building }\end{array}$ & 1 & Yes & \\
\hline & Scent landscape & 1 & Yes & \\
\hline \multicolumn{5}{|l|}{ Microclimate } \\
\hline & Acoustic comfort & 1 & Yes & \\
\hline \multicolumn{5}{|c|}{$\overline{\text { GUIDELINES AND CRITERIA RELATED TO MASTER PLAN }}$} \\
\hline Traffic control & & 1 & Yes & \\
\hline & $\begin{array}{c}\text { Streets friendly to } \\
\text { pedestrians }\end{array}$ & 1 & Yes & \\
\hline & Minimizing roads & 1 & $\begin{array}{l}\text { Underground } \\
\text { parking }\end{array}$ & \\
\hline \multicolumn{5}{|l|}{ Friendly public space } \\
\hline & Orientation enhancement & 1 & Yes & \\
\hline & $\begin{array}{c}\text { Ordered spatial } \\
\text { composition }\end{array}$ & 1 & Yes & \\
\hline & Architectural diversity & $1 / 2$ & Partially, forms of buildings & $\begin{array}{l}\text { It would be recommended to } \\
\text { promote more of architectural } \\
\text { variety }\end{array}$ \\
\hline & $\begin{array}{l}\text { Integrating buildings with } \\
\text { landscape }\end{array}$ & 1 & Yes & \\
\hline & Architectural details & 1 & Yes, high quality & \\
\hline & Esthetic qualities of space & 1 & Yes & \\
\hline & View through a window & $1 / 2$ & Partially & \\
\hline & Urban furniture & 1 & Yes & \\
\hline & $\begin{array}{l}\text { Legible hierarchy of public } \\
\text { and private space }\end{array}$ & 1 & Yes & \\
\hline \multicolumn{5}{|c|}{ Catering for basic needs of inhabitants within walking distance } \\
\hline & Functional diversity & $1 / 2$ & Limited & $\begin{array}{l}\text { It would be recommended to } \\
\text { promote more of functional } \\
\text { diversity }\end{array}$ \\
\hline
\end{tabular}


Table 3 (Continued). Assessment of sustainable development of eco-neighborhood-Gdynia Zachód

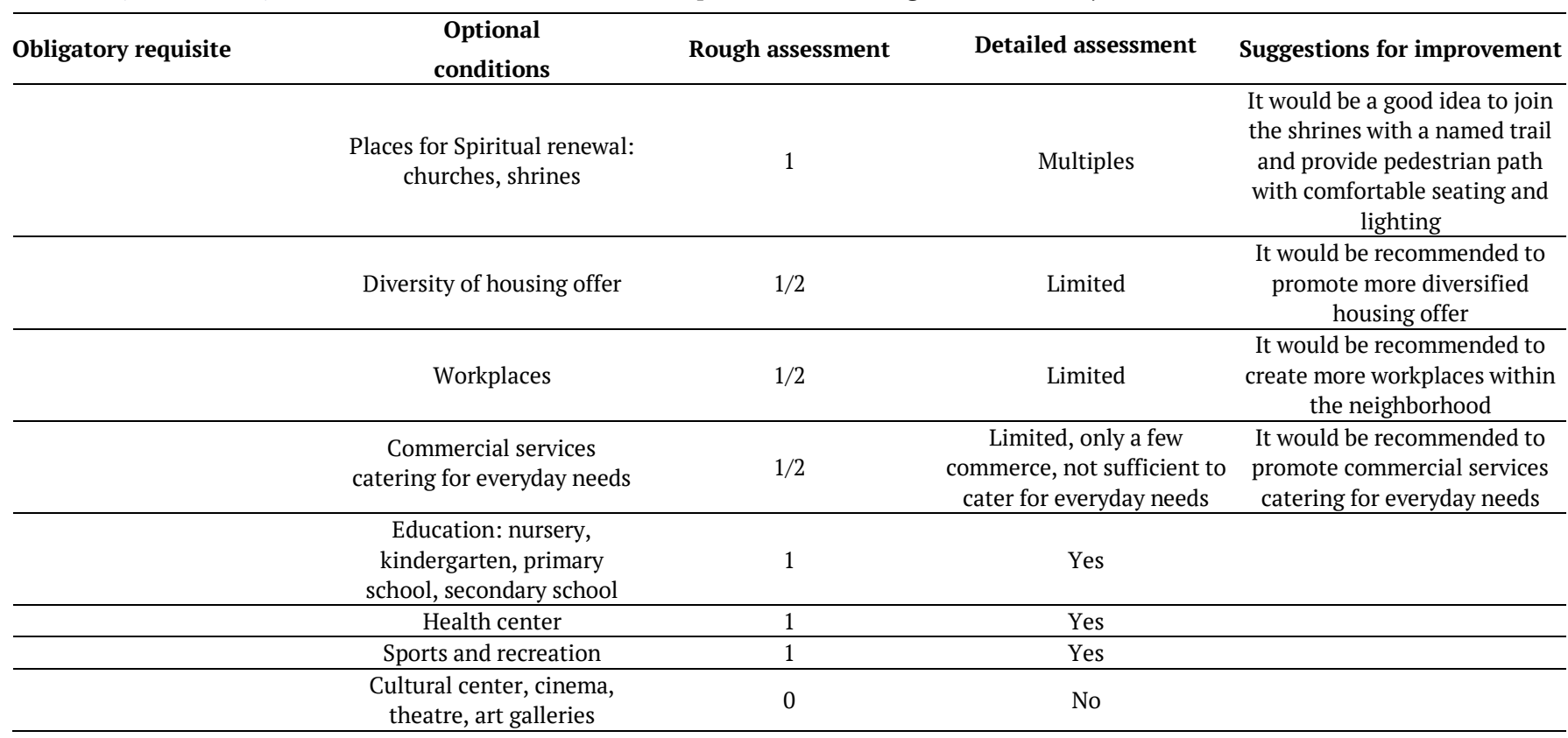

\section{CONCLUSIONS}

The universal standards are ready-to-use tools for the designers, developers, and the general public. They can be used to assess the therapeutic and health-promoting qualities of public space and the sustainable development of any housing project. The multicriteria assessment standards can also be used as justification tools to explain the design decisions to inhabitants, decision-makers, and local authorities. The individual assessment of the Gdynia-Zachód housing project demonstrated the vital points that should be developed and revealed some weak points that might be improved.

Funding: No external funding is received for this article.

Ethics approval and consent to participate: Not applicable.

Availability of data and materials: All data generated or analyzed during this study are available for sharing when appropriate request is directed to corresponding author.

\section{REFERENCES}

Alexander, C., Ishikawa, S. and Silverstein, M. (1977). A pattern language: Towns buildings construction. Oxford University Press.

Antonovsky, A. (1996). The salutogenic model as a theory to guide health promotion. Health Promotion International, 11(1), 11-18. https://doi.org/10.1093/heapro/11.1.11

Bell, S. (2012). Landscape: Pattern, perception and process. Routledge. https://doi.org/10.4324/9780203120088

Bell, S. L., Foley, R., Houghton, F., Maddrell, A. and Williams, A.M. (2017). From therapeutic landscapes to healthy spaces, places and practices: A scoping review. Social Science \& Medicine, 196, 123-130. https://doi.org/10.1016/ j.socscimed.2017.11.035
CABE. (2010). Community green: Using local spaces to tackle inequality and improve health. The Commission for Architecture and the Built Environment. https://www.designcouncil.org.uk/sites/default/files/asset /document/community-green-full-report.pdf

Corburn, J. (2009). Toward the healthy city. People, places, and the politics of urban planning. The MIT Press. https://doi.org/10.7551/mitpress/7583.001.0001

Denis, M., Cysek-Pawlak, M. M., Krzysztofik, S. and Majewska, A. (2021). Sustainable and vibrant cities. Opportunities and threats to the development of Polish cities. Cities, 109, 103014. https://doi.org/10.1016/j.cities.2020.103014

Edwards, P. and Tsouros, A. D. (2008). A healthy city is an active city: A physical activity planning guide. World Health Organization. https://www.euro.who.int/_data/assets/ pdf_file/0012/99975/E91883.pdf

Gerlach-Springs, N., Kaufman, R. E. and Warner, S. B. (1998). Restorative gardens: The healing landscape. Yale University Press.

Gesler, W. (1996). Lourdes: Healing in a place of pilgrimage. Health \& Place, 2(2), 95-105. https://doi.org/10.1016/13538292(96)00004-4

Gesler, W. (2005). Therapeutic landscapes: An evolving theme. Health \& Place, 11(4), 295-297. https://doi.org/10.1016/ j.healthplace.2005.02.003

Marcus, C. C. and Barnes M. (1995). Gardens in healthcare facilities: Uses, therapeutic benefits, and design recommendations. Center for Health Design. Available at: https://www.healthdesign.org/sites/default/files/Gardens \%20in\%20HC\%20Facility\%20Visits.pdf

Marcus, C. C. and Barnes, M. (1999). Healing gardens: Therapeutic benefits and design recommendations. John Wiley \& Sons.

Marcus, C. C. and Sachs, N. A. (2014). Therapeutic landscapes: An evidence-based approach to designing healing gardens and restorative outdoor spaces. John Wiley \& Sons. 
Mouratidis, K. (2021). Urban planning and quality of life: A review of pathways linking the built environment to subjective well-being. Cities, 115, 103229, https://doi.org/ 10.1016/j.cities.2021.103229

Register, R. (2006). Ecocities: Rebuilding cities in balance with nature. New Society Publishers.

Salingaros, N. A. and Masden, K. (2008). Neuroscience, the natural environment, and building design. In S. R. Kellert, J. Heerwagen and M. Mador (Eds.), Biophilic design: The theory, science, and practice of bringing buildings to life (pp. 59-83). John Wiley \& Sons.

Takano, T, Nakamura, K. and Watanabe, M. (2002). Urban residential environments and senior citizens' longevity in megacity areas: The importance of walkable green spaces. Journal of Epidemiology Community Health, 56(12), 913-918. https://doi.org/10.1136/jech.56.12.913

Trojanowska, M. (2017). Parki $i$ ogrody terapeutyczne [Therapeutic parks and gardens]. Wydawnictwo Naukowe PWN, Warszawa.

Trojanowska, M. (2018). Ekoosiedla. Kształtowanie zrównoważonych osiedli miejskich na przykładzie doświadczeń francuskich [Eco-neigbourhoods. Creating sustainable urban neighborhoods on the example of the French experience] Wydawnictwa Uczelniane Uniwersytetu Technologiczno-Przyrodniczego w Bydgoszczy, Bydgoszcz.

Trojanowska, M. (2019). Assessment of therapeutic qualities of ten public parks in Bydgoszcz. Budownictwo i Architektura [Construction and Architecture], 18(2), 121-143. https://doi.org/10.35784/bud-arch.559

Trojanowska, M. (2020). Therapeutic qualities and sustainable approach to heritage of the city. The coastal strip in Gdańsk, Poland. Sustainability, 12(21), 9243. https://doi.org/10.3390/su12219243
Trojanowska, M. (2021a). A universal standard for healthpromoting places. Example of assessment-on the basis of a case study of Rahway River Park. Budownictwo $i$ Architektura [Construction and Architecture], 20(3), 57-84. https://doi.org/10.35784/bud-arch.2715

Trojanowska, M. (2021b). Architectural strategies that promote creation of social bonds within econeighbourhoods. Space \& FORM, 46, 195-210. https://doi.org/10.21005/pif.2021.46.C-07

Trojanowska, M. and Sas-Bojarska, A. (2018). Health-affirming everyday landscapes in sustainable city. Theories and tools. Architecture, Civil Engineering, Environment, 11(3), 41-52. https://doi.org/10.21307/ACEE-2018-037

Ulrich, R. S. (2008). Biophilic theory and research for healthcare design. In S. R. Kellert, J. H. Heerwagen and M. L. Mador (Eds.), Biophilic design: The theory, science, and practice of bringing buildings to life (pp. 87-106). John Wiley \& Sons.

Wakefield, S. and McMullan, C. (2006). Healing in places of decline: (Re)imagining everyday landscapes in Hamilton, Ontario. Health \& Place, 11(4), 299-312. https://doi.org/ 10.1016/j.healthplace.2004.05.001

Webster, C., Sarkar, C. and Gallacher, J. (2014). Healthy cities: Public health through urban planning. Edward Elgar Publishing. https://doi.org/10.4337/9781781955727

Wilkonson, R. and Marmot, M. (Eds.). (2003). Social determinants of health: The solid facts. World Health Organization. Available at: https://www.euro.who.int/ data/assets/pdf_file/0005/98438/e81384.pdf 


\section{APPENDIX A}

Universal Standard for Health-Promoting Urban Places

\begin{tabular}{|c|c|c|c|c|c|}
\hline UNIVERSAL DESIGN & $\begin{array}{c}\text { PARK'S } \\
\text { FUNCTIONAL } \\
\text { PROGRAM } \\
\end{array}$ & $\begin{array}{c}\text { ORGANIZATION OF } \\
\text { SPACE AND } \\
\text { FUNCTIONS } \\
\end{array}$ & PLACEMAKING & SUSTAINABILITY & ACCESS TO PARK \\
\hline $\begin{array}{c}\text { 1. Place } \\
\text { Area } \\
\text { Location } \\
\text { Surrounding urban } \\
\text { pattern } \\
\text { 2. Environmental } \\
\text { characteristics } \\
\text { Soil quality } \\
\text { Water quality } \\
\text { Air quality } \\
\text { Biodiversity } \\
\text { Forms of nature } \\
\text { protection } \\
\text { 3. Universal } \\
\text { accessibility } \\
\text { 4. Access to park } \\
\text { Distance to potential } \\
\text { users } \\
\text { Public transport stops } \\
\text { Walkways to park }\end{array}$ & $\begin{array}{l}\text { 1. Psychological and } \\
\text { physical } \\
\text { regeneration } \\
\text { Natural landscapes } \\
\text { Green open space } \\
\text { Place to rest in the sun } \\
\text { and in the shade } \\
\text { Place to rest in silence } \\
\text { and solitude } \\
\text { Possibility to observe } \\
\text { other people } \\
\text { Possibility to observe } \\
\text { animals } \\
\text { 2. Social contacts } \\
\text { enhancement } \\
\text { Organization of events } \\
\text { inside the park } \\
\text { Gathering place for } \\
\text { groups } \\
\text { 3. Physical activity } \\
\text { promotion } \\
\text { Sports and } \\
\text { recreational } \\
\text { infrastructure } \\
\text { Community gardens } \\
\text { 4. Catering for basic } \\
\text { needs } \\
\text { Safety and security } \\
\text { Places to sit and rest } \\
\text { Shelter } \\
\text { Restrooms } \\
\text { Drinking water } \\
\text { Food }\end{array}$ & $\begin{array}{l}\text { 1. The park spatial } \\
\text { composition follows } \\
\text { the surrounding } \\
\text { urban pattern } \\
\text { 2. Architectural } \\
\text { variety of urban } \\
\text { environment } \\
\text { Focal points and } \\
\text { landmarks } \\
\text { Structure of interiors } \\
\text { and connections } \\
\text { Long vistas (Extent) } \\
\text { Pathways with views } \\
\text { Invisible fragments of } \\
\text { the scene (Vista } \\
\text { engaging the } \\
\text { imagination) } \\
\text { Mystery, fascination } \\
\text { Framed views } \\
\text { Human scale } \\
\text { 3. Optimal level of } \\
\text { complexity } \\
\text { 4. Natural surfaces } \\
\text { 5. Engaging features } \\
\text { Risk/Peril } \\
\text { Movement } \\
\text { 6. Presence of water } \\
\text { 7. Sensory stimuli } \\
\text { design } \\
\text { Sensory stimuli: Sight } \\
\text { Sensory stimuli: } \\
\text { Hearing } \\
\text { Sensory stimuli: Smell } \\
\text { Sensory stimuli: } \\
\text { Touch } \\
\text { Sensory stimuli: Taste } \\
\text { Sensory path }\end{array}$ & $\begin{array}{l}\text { 1. Works of art } \\
\text { 2. Monuments in the } \\
\text { park } \\
\text { 3. Historic places } \\
\text { Culture and } \\
\text { connection } \\
\text { to the past } \\
\text { 4. Thematic gardens } \\
\text { 5. Personalization } \\
\text { 6. Animation of } \\
\text { place } \\
\text { 7. Community } \\
\text { engagement } \\
\text { Personalising the } \\
\text { architectural process } \\
\text { Participation of all } \\
\text { stakeholders, } \\
\text { including inhabitants } \\
\text { and users } \\
\text { Determining the rules } \\
\text { of conduct and self- } \\
\text { management } \\
\text { 8. Space for social } \\
\text { contact } \\
\text { Third places } \\
\text { Fourth places }\end{array}$ & $\begin{array}{c}\text { 1. Green } \\
\text { infrastructure } \\
\text { 2. Parks of second } \\
\text { (New) generation } \\
\text { 3. Biodiversity } \\
\text { protection } \\
\text { Part of park not- } \\
\text { available to visitors } \\
\text { Native plants } \\
\text { Native animals } \\
\text { Natural maintenance } \\
\text { methods } \\
\text { 4. Sustainable water } \\
\text { management } \\
\text { Rainwater infiltration } \\
\text { Irrigation with non- } \\
\text { potable water } \\
\text { Park in a flood risk } \\
\text { zone } \\
\text { 5. Urban metabolism }\end{array}$ & $\begin{array}{c}\text { 1. Sidewalk } \\
\text { infrastructure } \\
\text { Width of sidewalk } \\
\text { Evenness of surface } \\
\text { Lack of obstructions } \\
\text { Slope } \\
\text { Sufficient drainage } \\
\text { 2. General conditions } \\
\text { Maintenance } \\
\text { Overall aesthetics } \\
\text { Street art } \\
\text { Sufficient seating } \\
\text { Perceived safety } \\
\text { Buffering from traffic } \\
\text { Street activities } \\
\text { Vacant lots } \\
\text { 3. Traffic } \\
\text { Speed } \\
\text { Volume } \\
\text { Number and safety of } \\
\text { crossings } \\
\text { Stop signs } \\
\text { Parking } \\
\text { 4. User experience } \\
\text { Air quality } \\
\text { Noise level } \\
\text { Sufficient lighting } \\
\text { Sunshine and shade } \\
\text { Transparency of } \\
\text { ground floors of } \\
\text { building }\end{array}$ \\
\hline
\end{tabular}

Source: Trojanowska (2021a) 


\section{APPENDIX B}

Universal Standard for Sustainable Eco-Neighborhoods

\begin{tabular}{|c|c|c|c|}
\hline & PLANNING OF DEVELOPMENT & $\begin{array}{l}\text { SUSTAINABLE DEVELOPMENT AND } \\
\text { INHABITANTS HEALTH PROMOTION }\end{array}$ & $\begin{array}{l}\text { GUIDELINES AND CRITERIA } \\
\text { RELATED TO MASTERPLAN }\end{array}$ \\
\hline $\begin{array}{l}\text { Obligatory } \\
\text { requisite }\end{array}$ & $\begin{array}{l}\text { Integrated design } \\
\text { Consolidation of social capital } \\
\text { Accessible public transport } \\
\text { Restraining the suburban sprawl } \\
\text { Positive economic impact for the city and } \\
\text { region }\end{array}$ & $\begin{array}{l}\text { Open public green space } \\
\text { Public park in the center of } \\
\text { neighborhood to be developed first } \\
\text { Green infrastructure grid } \\
\text { Water protection } \\
\text { Soil protection } \\
\text { Air protection } \\
\text { Microclimate }\end{array}$ & $\begin{array}{l}\text { Traffic control } \\
\text { Friendly public space } \\
\text { Catering for basic needs of } \\
\text { inhabitants within walking distance }\end{array}$ \\
\hline $\begin{array}{l}\text { Optional } \\
\text { conditions }\end{array}$ & $\begin{array}{l}\text { Consolidation of social capital } \\
\text { Participation } \\
\text { Space for social contacts } \\
\text { Restraining the suburban sprawl } \\
\text { Revitalization of brownfields }\end{array}$ & $\begin{array}{l}\text { Open public green space } \\
\text { Public park in the center of } \\
\text { neighborhood to be developed first } \\
\text { Therapeutic park } \\
\text { New (second) generation of parks } \\
\text { Community gardens } \\
\text { Green infrastructure grid } \\
\text { Green streets } \\
\text { Green walls } \\
\text { Green roofs } \\
\text { Biodiversity Protection } \\
\text { Enclosure for pets } \\
\text { Water protection } \\
\text { Sustainable drainage systems } \\
\text { Stabilized permeable surfaces } \\
\text { Open drainage canals } \\
\text { Swales for drainage } \\
\text { Swales for infiltration and retention } \\
\text { Raingardens } \\
\text { Dry basins } \\
\text { Artificial wetlands } \\
\text { Soil Protection } \\
\text { Installations fo phytoremediation } \\
\text { Minimizing the building footprint } \\
\text { Urban metabolism, "zero" waste } \\
\text { Pneumatic waste collection } \\
\text { Natural maintenance of green areas } \\
\text { Composting green waste } \\
\text { Air protection } \\
\text { Ecological heating } \\
\text { HVAC } \\
\text { Natural daylight } \\
\text { Energy efficiency of individual } \\
\text { buildings } \\
\text { Factory landscape } \\
\text { Microclimate } \\
\text { Acoustic comfort } \\
\end{array}$ & $\begin{array}{l}\text { Traffic control } \\
\text { Streets friendly to pedestrians } \\
\text { Minimizing roads } \\
\text { Friendly public space } \\
\text { Easy orientation } \\
\text { Ordered spatial composition } \\
\text { Architectural diversity } \\
\text { Integrating buildings with } \\
\text { landscape } \\
\text { Architectural details } \\
\text { Esthetic qualities of space } \\
\text { View through a window } \\
\text { Urban furniture } \\
\text { Legible hierarchy of public and } \\
\text { private space } \\
\text { Catering for basic needs of } \\
\text { inhabitants within walking distance } \\
\text { Functional diversity } \\
\text { Places for Spiritual renewal: } \\
\text { churches, shrines } \\
\text { Diversity of housing offer } \\
\text { Workplaces } \\
\text { Commercial services } \\
\text { Education: nursery, kindergarten, } \\
\text { primary school, secondary school } \\
\text { Sports and recreation facilities } \\
\text { Cultural center, cinema, theatre, } \\
\text { art galleries }\end{array}$ \\
\hline
\end{tabular}

Source: Trojanowska (2018) 